\title{
S. Frederick Starr (ed.), Xinjiang. China's Muslim
}

\section{Borderland}

London, Armonk, NY, M.E. Sharpe, 2004, 506 p.

\section{Rémi Castets}

\section{OpenEdition}

\section{Journals}

Édition électronique

URL : http://journals.openedition.org/chinaperspectives/644

DOI : 10.4000/chinaperspectives. 644

ISSN : 1996-4617

Éditeur

Centre d'étude français sur la Chine contemporaine

Édition imprimée

Date de publication : 1 juin 2006

ISSN : 2070-3449

\section{Référence électronique}

Rémi Castets, «S. Frederick Starr (ed.), Xinjiang. China's Muslim Borderland», China Perspectives [En

ligne], 65 I may - june 2006, mis en ligne le 21 décembre 2006, consulté le 22 septembre 2020. URL :

http://journals.openedition.org/chinaperspectives/644; DOI : https://doi.org/10.4000/

chinaperspectives.644

Ce document a été généré automatiquement le 22 septembre 2020

(C) All rights reserved 


\title{
S. Frederick Starr (ed.), Xinjiang. China's Muslim Borderland
}

\author{
London, Armonk, NY, M.E. Sharpe, 2004, 506 p.
}

Rémi Castets

\section{NOTE DE L'ÉDITEUR}

Translated from the French original by Michael Black

1 This book is the result of a research programme launched by the East West Center in Washington in 1998. It brings together contributions from 16 specialists. The younger of them have taken advantage of the relative opening up of the region over the last twenty years to carry out long-term research. They have returned with a knowledge of the field and linguistic skills that have regenerated research on Xinjiang. The groundbreaking and rigorous characteristics of this book are largely due to the sharing of the talents of this new generation with those of their elders.

2 As Frederick Starr emphasises in the introductory chapter, China's Muslim Borderland takes as its point of departure a recognition that Xinjiang is deeply influenced by the particularities of its Turkic Muslim populations. The book is mainly centred on a study of the modalities and problems arising from the integration of this marginal territory into the modern Chinese state. It analyses the policies of control and government implemented by Beijing, as well as their effects and the reactions of the indigenous populations to which they give rise. The contributors examine this dialogical relationship through a variety of prisms (historical, political, military, economic, educational, demographic, sanitary, religious and socio-cultural). These viewpoints, which both complement and overlay each other, allow the reader in the course of the book to acquire an overall vision of the problem.

3 The first part of the book provides a fine-meshed and rigorous framework of the history of the region up to 1978. James Millward and Peter C. Perdue first describe the main events that led to the formation of the ethno-cultural landscape of this territory, 
which was coveted from very early times by both the empires of the steppe and the most powerful Chinese dynasties. The authors highlight in the background the summaries and distortions which stud competing versions of history driven by nationalist logic. They emphasise on the one hand the existence of an official version, the only one allowed in Xinjiang today, which is subjected to the Chinese state's determination to legitimise its sovereignty. This is in competition with a version influenced by Uyghur anti-colonial nationalism. The latter in contrast supports the idea that the region belongs to a cultural universe that is foreign to China, and has experienced a history cut off from the Chinese world. In the second chapter, James Millward and Nabijan Tursun examine the period from 1884 to 1978, during which Xinjiang began to be integrated into the rest of China. The emergence of Uyghur anticolonial opposition appears here both to follow the spreading of Western modernism and to be a reaction to Chinese colonial policies. The authors paint a picture, up to the first years of coming under the authority of the Chinese communists, of a complex political context shaken by a variety of forces (the provincial authorities, the Guomindang, the Soviets, nationalist pan-Turkic and pro-Soviet Uyghur, the Dungan ${ }^{2}$ ). The following period was marked by the reassertion of Beijing's authority over the region and by an acceleration of integration with China, in particular through massive demographic colonisation and tight political control.

4 The second part of the book is devoted to the strategies of control implemented from the centre. Dru Gladney analyses the various aspects of the policies of control set up by the Chinese communist regime and their limitations. He emphasises the subtleties of a process of ethnic labelling controlled by the Chinese regime, which pays for the acceptance of ethnic identities defined in such a way as to be aimed at insertion into the Chinese nation. Yitzhak Shichor examines the decisive role of the Chinese army in the region since 1949. He offers a highly detailed chronology of the events that have involved an army tightly bound up with the regional government. Despite the tensions stemming from the China-USSR and China-India conflicts, and despite their key role in the repression of local insurrections, the author emphasises the relative weakness of the military forces in the region. He also provides comparatively little-known information on the actions of the American intelligence services in the region, as well as recalling China's support for the Afghan Mujahideen. When he comes to link the previous question with the threat posed by Uyghur militancy, the author, using secondary sources from the press and from the Chinese and Pakistani intelligence services, tends to give a somewhat distorted and conventional image of a violent Uyghur opposition linked to international jihad. Such information has been in circulation for a long time. However, in the light of its potential instrumentalisation by local regimes, it is in need of confirmation and support. The author could also have emphasised the unusual role played by the Xinjiang Construction and Development Corps (bingtuan) in the strategy of control and development in the region. However, this does not detract from the quality of the article, which provides a considerable amount of information.

In the third part, which deals with the internal situation, Calla Wiemer presents the main features of the local economy, with a history of the various sectors of activity and the small share of external trade. Her analysis highlights the considerable extent of the state sector and of the inequalities in income that follow ethnic lines. In the following chapter, Linda Benson analyses the changes in the education system and its 
fundamental importance in the process of integrating the region into the rest of China. She draws a balanced picture, emphasising the progress made since the Republican period, but also the weaknesses in the system : the under-representation of minorities, the difficulties that Uyghur graduates face in finding employment, and the threat posed by a system tending more and more to become one of assimilation. In the following chapter, Sean Roberts studies the influences of the outside world and of the diaspora on Xinjiang. In particular, he assesses the influence of Pakistani muslims, and of Uyghur nationalists from the diaspora, as well as the strategies implemented by China in order to counter these influences.

6 In the fourth part of the book, which deals with the impact of development and control policies, Stanley Toops presents a demographic study of the region. He states in his introduction that the use "of statistics produced by the State Bureau of Statistics provides an excellent overview of the structure of the population in Xinjiang". Some will tax him with a somewhat excessive confidence in the quality and reliability of such data. Having said that, these data are the only ones available, and they constitute a good indication in terms of trends. Thus, after establishing a historical perspective on demographic evolutions, the author offers through a series of maps an interesting superimposition of the region's ethnic distribution, migration patterns and economic dynamism. This approach first singles out the areas subjected to colonial pressures, and then draws a correlation between ethnicity and prosperity, which penalises the Uyghur. He offers in the following chapter a brief human and physical geography that emphasises the increasing pressures on limited water resources. Jay Dautcher highlights an explosive health situation : the worrying increase in heroin consumption is closely linked with the AIDS epidemic.

7 In the last part, which deals with the response of the "indigenous populations", Justin Rudelson and William Jankowiak draw up a chronology of the policies of cultural integration and control, which oscillate between "hard policies" and "soft policies". They recall, as does the book by Justin Rudelson ${ }^{3}$, the reactions of the Uyghur in the face of the latter, as well as the factors that contribute to weakening the solidarity between them and the central state.

8 Graham Fuller and Jonathan Lipman show the extent to which Islam has historically been a vector of opposition as well as a vector of differentiation for those who reject assimilation. They show how in return the muslim identity of the local populations has been reined in, controlled or instrumentalised by a Chinese state anxious to close the channels through which any opposition might make itself heard. In the footsteps of Eric Hobsbawm, Gardner Bovingdon offers in the next chapter a revised version of some of his research on the rewriting of the history of Xinjiang by both the Chinese state and Uyghur nationalism. This study, which contains a rich store of Chinese and Uyghur references, is one of the most advanced pieces of work on the subject. Lastly, in the final chapter, Dru Gladney provides a study of the means of expression used by the Uyghur opposition. He emphasises their evolution according to local socio-political and international context. In particular he shows how the use of the Internet could favour the emergence of a virtual militant community.

9 All in all, even if some chapters are revised versions of articles published elsewhere, the book presents a good compromise between innovation and synthesis. Some will criticise it for being too highly Anglo-Saxon and even American-centred. Indeed, only one Uyghur co-author (Nabijan Tursun) is included. Also to be regretted is the placing 
of the notes at the end of the volume, which leads to constant to-ing and fro-ing between the chapters and the back of the book. These slight criticisms apart, China's Muslim Borderland is a "must read" and certainly one of the best publications on the region in the last few years.

\section{NOTES DE FIN}

1. This programme has given rise to a number of reports on Xinjiang which can be found on the website of the East West Center in Washington (http :// www.eastwestcenterwashington.org).

2. Later designated by the name Hui.

3. Justin Rudelson, Oasis Identities : Uyghur Nationalism Along China's Silk Road, New York, Columbia University Press, 1997, 209 pp. 